\title{
Konsep Small Claim Procedure Untuk Menyelesaikan Perkara Perdata Permohonan (Volunter) Di Pengadilan Agama
}

\author{
Muharrom Ainul Yaqin \\ Fakultas Syariah UIN Maulana Malik Ibrahim Malang \\ niqay12@yahoo.co.id
}

\begin{abstract}
:
This article aims to formulate the concept of small claims procedure that can be used to check the examination of civil cases in the court petition religion, as well as describe the types of cases that can be checked by using a system of small claims procedure. The concept of small claims procedure can be applied in religious courts, to examine and decide cases petition (volunteer) with consideration of the substance of the case filed is simple. Nevertheless, the judges who hear cases iniharus memeliki experience and proficiency in handling the case of the petition. For the system to be enforced in court, this concept needs to be formulated in the form of Supreme Court Regulation. An application includes a simple matter if it has the value of materials or rights that are simple, the application is simple, and it is possible to be examined in one trial. Based on these criteria, there are eight types of cases that can be checked using a system of small claims procedure are: the permit application mating, pleas guardian adhol, request dispensation mating, pleas prevention marriage, request the establishment of origin of the child, the request istbat marriage, requesting to change the identity of marriage, and request the appointment of a guardian.
\end{abstract}

Artikel ini bertujuan merumuskan konsep small claim procedure yang dapat digunakan untuk memeriksa pemeriksaan perkara perdata permohonan di pengadilan agama, serta mendeskripsikan jenis perkara yang dapat diperiksa dengan menggunakan sistem small claim procedure. Konsep small claim procedure dapat diterapkan di pengadilan agama, untuk memeriksa dan memutus perkara permohonan (volunter) dengan pertimbangan substansi perkara yang diajukan bersifat sederhana. Meskipun demikian, hakim yang memeriksa perkara iniharus memeliki pengalaman dan kecakapan dalam menangani perkara permohonan. Agar sistem ini dapat diberlakukan di pengadilan, konsep ini perlu dirumuskan dalam bentuk Peraturan Mahkamah Agung. Suatu permohonan termasuk perkara yang sederhana jika memiliki nilai materi atau hak yang sederhana, permohonannya sederhana, dan sangat memungkinkan untuk diperiksa dalam satu kali sidang. Berdasarkan kriteria tersebut, ada delapan jenis perkara yang dapat diperiksa menggunakan sistem small claim procedure yaitu: permohonan izin kawin, permohonan wali adhol, permohonan dispensasi kawin, permohonan pencegahan perkawinan, permohonan penetapan asal-usul anak, permohonan istbat nikah, permohonan perubahan identitas nikah, dan permohonan pengangkatan wali.

Kata Kunci: small claim procedure; permohonan; pengadilan agama 


\section{Pendahuluan}

Sebagai salah satu cabang kekuasaan negara, kekuasaan kehakiman di Indonesia dilaksanakan oleh Mahkamah Agung dan badan peradilan yang berada di bawahnya yaitu peradilan umum, peradilan agama, peradilan militer, dan peradilan tata usaha negara serta oleh Mahkamah Konstitusi. Sebagaimana diatur dalam Pasal 24 ayat (2) Undang-Undang Dasar Negara Republik Indonesia. ${ }^{1}$ Masing-masing peradilan memiliki ciri khas dan kompetensi yang berbeda. Di lingkungan peradilan umum, hampir semua perkara dan semua orang dapat mengajukan perkara kepadanya. Namun, terdapat pula lingkungan peradilan yang bersifat khusus, dimana tidak semua perkara atau semua orang dapat mengajukan perkaranya. Peradilan agama misalnya, peradilan ini merupakan memeriksa, memutus, dan menyelesaikan perkara perdata tertentu bagi orang-orang Islam atau mereka yang menundukkan diri terhadap hukum Islam. $^{2}$

Kekuasaan kehakiman di Indonesia dilaksanakan berdasarkan hukum dan asas-asas peradilan yang berlaku. Salah satunya adalah asas sederhana, cepat, dan biaya ringan. Dalam konteks peradilan agama, asas ini diatur dalam Pasal 57 ayat (3) Undang-Undang Nomor 7 tahun 1989 tentang Peradilan Agama yang berbunyi "Peradilan dilakukan dengan sederhana, cepat, dan biaya ringan". Dalam penjelasannya, asas tersebut merupakan tindak lanjut dari amanat yang telah diamanatkan di dalam Undang-Undang Nomor 14 Tahun 1970 tentang Ketentuan-ketentuan Pokok Kekuasaan Kehakiman yang kemudian diubah dengan UndangUndang Nomor 4 Tahun 2004 tentang Kekuasaan Kehakiman dan Undang-Undang Nomor 48 Tahun 2009 tentang Kekuasaan Kehakiman.

Sejak tahun 1989, asas sederhana, cepat, dan biaya ringan secara resmi telah menjadi asas dasar pengadilan agama. Meskipun demikian, asas tersebut belum mampu dijalankan secara maksimal. Pemeriksaan melalui jalur litigasi memberikan kepastian hukum yang mengikat, namun dirasa kurang efektif dan efisien. Masih banyak perkara yang tidak dapat diputus setiap bulannya. Selain itu, berdasarkan pra riset yang peneliti lakukan, butuh waktu rata-rata sekitar 27,8 hari untuk menyelesaikan setiap perkara perdata permohonan yang ada di semua pengadilan agama di Jawa Timur. ${ }^{3} \mathrm{Hal}$ ini menunjukkan bahwa asas sederhana, cepat, dan biaya ringan belum dapat dilaksanakan secara maksimal.

Salah satu solusi yang sedang digagas oleh Mahkamah Agung adalah pemeriksaan perkara dengan menggunakan sistem small claim procedure. Menurut Efa Laela Fakhriah small claim procedure adalah suatu mekanisme pengadilan yang bersifat informal (di dalam pengadilan tetapi mekanismenya di luar mekanisme pengadilan pada umumnya) dengan pemeriksaan perkara yang cepat untuk mengambil keputusan atas tuntutan ganti kerugian atau utang piutang yang nilai gugatannya kecil. ${ }^{4}$ Small claim procedure merupakan sebuah sistem pemeriksaan perkara dengan cara yang sangat sederhana. Harapan dari penggunaan sistem ini adalah agar asas peradilan yang sederhana, cepat, dan biaya ringan dapat terlaksana secara maksimal. Small claim procedure menawarkan suatu sistem pemeriksaan perkara yang sangat sederhana, dimana sebelum melakukan pemeriksaan, perkara yang akan diperiksa harus merupakan perkara yang memiliki nilai sengketa yang kecil. Oleh karena perkara tersebut bernilai gugatan kecil, maka pemeriksaan dapat dilakukan dengan sederhana namun tidak mengurangi kejelian dan ketelitian dari hakim yang memeriksa.

Pemeriksaan yang sederhana tersebut dapat berimbas pada waktu pemeriksaan serta biaya yang harus dikeluarkan oleh para pihak. Waktu yang dibutuhkan untuk memeriksa perkara

\footnotetext{
${ }^{1}$ Pasal 24 ayat (2) Undang-Undang Dasar Negara Republik Indonesia

2 Pasal 1 ayat (1) Undang-Undang Nomor 50 tahun 2009 tentang Peradilan Agama

${ }^{3}$ Peneliti mengambil sample perkara permohonan di semua PA di Jawa Timur, kemudian setiap perkara dihitung membutuhkan berapa hari dari tanggal register hingga putusan dibacakan, kemudian diambil rata-ratanya.

4"MA Upayakan Inisiasi Penyelesaian Gugatan Perdata Sederhana," October 28, 2014, http://www.pembaruanperadilan.net/v2/2014/04/ma-upayakan-inisiasi-penyelesaian-gugatan-perdata-sederhana/.
} 
menjadi semakin singkat dan secara otomatis biaya yang dikeluarkan juga tidak banyak. Tujuan dan harapan itulah yang dapat diwujudkan dengan penggunaan sistem small claim procedure. Jenis perkara permohonan sangat memungkinkan untuk diperiksa dengan menggunakan sistem small claim procedurekarena sifat-sifat yang dimilikinya. Salah satu sifat yang dimiliki perkara permohonan adalah tidak adanya sengketa, yang mana sengketa merupakan salah satu instrumen yang dapat memperlama pemeriksaan suatu perkara. Pada dasarnya, sistem small claim procedure yang telah berlaku di negara-negara maju digunakan untuk memeriksa perkara gugatan atau perkara yang mengandung sengketa. Logikanya, perkara yang mengandung sengketa dapat diperiksa dengna menggunakan sistem small claim procedure, terlebih perkaraperkara yang tidak mengandung sengketa akan lebih baik lagi jika diperiksa dengan menggunakan acara pemeriksaan dengan sederhana dan cepat, namun sampai saat ini belum ada regulasi maupun konsep yang mengaturnya. Oleh sebab itu, peneliti tertarik untuk membuat penelitian yang bertemakan konsep small claim procedure untuk memeriksa perkara perdata permohonan di pengadilan agama. Berdasarkan paparan di atas, artikel ini bertujuan merumuskan konsep small claim procedure yang dapat digunakan untuk memeriksa pemeriksaan perkara perdata permohonan di pengadilan agama, serta mendeskripsikan jenis perkara yang dapat diperiksa dengan menggunakan sistem small claim procedure.

\section{Metode Penelitian}

Penelitian ini termasuk dalam penelitian yuridis normatif karena menggunakan sumber data sekunder sebagai bahan penelitian. ${ }^{5}$ Penelitian ini menggunakan pendekatan konseptual. Karena objek yang sedang dibahas dalam penelitan ini belum diatur dalam peraturan perundang-undangan. Peneliti menggunakan asas hukum sebagai acuannya dalam melakukan penelitian. ${ }^{6}$ Dalam penelitian ini peneliti beranjak dari asas-asas yang ada di dalam Pasal 57 ayat (3) Undang-Undang Nomor 7 Tahun 1989 tentang Peradilan Agama yaitu asas sederhana, cepat, dan biaya ringan untuk merumuskan small claim procedure yang dapat digunakan untuk memeriksa perkara perdata permohonan di pengadilan agama. Bahan hukum primer yang digunakan yaitu Undang-Undang Nomor 7 Tahun 1989 jo. Undang-Undang Nomor 3 Tahun 2006 Jo. Undang-Undang Nomor 50 Tahun 2009 tentang Peradilan Agama. Sedangkan bahan hukum sekunder yang digunakan adalah jurnal dan buku-buku yang terkait dengan small claim procedure. ${ }^{7}$ Semua bahan hukum tersebut kemudian dianalisis secara deskriptif kualitatif yang tidak lepas dari jenis penelitian yang normatif. Hasil dari analisis juga disimpulkan dengan cara deskriptif yang kemudian disebut dengan penelitian kualitatif normatif.

\section{Hasil dan Pembahasan}

\section{Konsep Umum Small Claim Procedure}

Small claim procedure belum banyak dikenal dalam literatur hukum di Indonesia. Mahkamah Agung dalam laman resminya memberikan istilah "Pengadilan Rakyat" untuk menyebut pengadilan yang memakai small claim procedure. ${ }^{8}$ Prosedur beracara dengan cara sederhana telah diberlakukan di beberapa negara, seperti Amerika Serikat, Australia, Australia, Irlandia, Inggris, Norwegia, dan lain sebagainya. ${ }^{9}$ Pemeriksaan perkara perdata dengan menggunakan sistem small claim prcedure merupakan pemeriksaan perkara dengan cara litigasi

\footnotetext{
${ }^{5}$ Amiruddin and Zainal Asikin, Pengantar Metode Penelitian Hukum (Jakarta: RajaGrafindo Persada, 2012), 118.

${ }^{6}$ Peter Mahmud Marzuki, Penelitian Hukum (Jakarta: Kencana, 2010), 137.

${ }^{7}$ Marzuki, Penelitian Hukum, 141.

8"Mahkamah Agung Republik Indonesia," accessed December 8, 2016, https://www.mahkamahagung.go.id/id/berita/361/pengadilan-untuk-semua.

${ }^{9}$ Efa Laela Fakhriah, "Mekanisme Small Claim Court Dalam Mewujudkan Tercapainya Peradilan Sederhana, Cepat, Dan Biaya Ringan,” Mimbar Hukum 25, no. 2 (April 2013): 265.
} 
namun memiliki perbedaan dengan sistem pemeriksaan pada umumnya. Perbedaan yang paling menonjol adalah kesederhanaannya. Sistem small claim prcedure menghendaki pemeriksaan perkara perdata dengan cara yang sangat sederhana. ${ }^{10}$ Badan hukum yang kemudian ditunjuk sebagai pengguna sistem small claim procedure disebut sebagai small claim court.

Lee P. Arbetman, Edward T. McMahon, dan Edward L. O'Brien dalam bukunya yang berjudul Street Law: A Course in Practicial Law menyebutkan bahwa dalam istilah lain, small claim court disebut jugadengan istilah "People's Court". ${ }^{11}$ Menurut Efa Laela yang mengutip dari Steven Weller, John C. Ruhnka, dan John A. Martin ada 5 (lima) komponen utama small claim procedure, antara lain adalah: 1) pengurangan biaya pengadilan; 2) penyederhanaan proses permohonan atau pengajuan gugatan; 3) prosedur penyelesaian sebagian besar diserahkan kepada kebijaksanaan hakim pengadilan dengan pembuktian yang sederhana; 4) hakim dan panitera pengadilan diharapkan dapat membantu pihak yang beperkara, baik dalam persiapan pengajuan gugatan dan pemeriksaan perkara di pengadilan, sehingga tidak diperlukan perwakilan oleh pengacara; 5) hakim diberi kewenangan untuk memerintahkan pembayaran secara langsung atau melalui angsuran. ${ }^{12}$ Tujuan penerapan small claim procedure adalah memberikan fasilitas bagi para pihak untuk memohonkan pemeriksaan perkaranya yang tergolong kecil. Dengan kriteria sebagai berikut: 1) nilai sengketa atau gugatannya kecil, tidak melebihi Rp. 100.000.000,- (seratus juta rupiah); 2) permasalahannya tidak kompleks; 3) tuntutan haknya sederhana dan tidak banyak; 4) paling banyak 3 (tiga) kali sidang). ${ }^{13}$

Mahkamah Agung telah berinisiasi menyusun regulasi tentang penerapan sistem small claim procedure di lembaga peradilan yang ada di bawahnya. Namun ruang lingkupnya hanya terbatas untuk digunakan memeriksa perkara perdata sengketa bisnis saja. Hal ini tidak jauh berbeda dengan negara-negara yang telah menerapkan sistem small claim procedure. Menurut penulis sistem small claim procedure juga dapat digunakan untuk memeriksa perkara perdata permohonan di lingkungan peradilan agama, yang setiap tahun cenderung meningkat setiap tahunnya. Sebab, permohonan tidak mengandung unsur sengketa, berbeda dengan gugatan yang mengandung sengketa. Jika sistem small claim procedure diberlakukan, hal ini merupakan pembaharuan hukum di Indonesia, khusususnya pembaharuan dalam bidang hukum acara. Dalam sistem ini perkara yang masuk pengadilan agak dibedakan menjadi dua, yaitu perkara sederhana dan perkara kompleks. Perkara sederhanak akan diperiksa menggunakan small claim procedure. Perkara-perkara yang bersifat sederhana dapat diperiksa lebih cepat tanpa proses yang rumit seperti halnya pemeriksaan perkara yang memiliki masalah yang kompleks. Selain perkaranya yang telah ditentukan di awal, sistem small claim procedure juga menghendaki adanya hakim tunggal dalam pemeriksaannya. Peneliti berpendapat bahwa pemeriksaan perkara permohonan yang tidak mengandung unsur sengketa dan dapat dikatakan perkara tersebut sangat sederhana, yang dapat diperiksa hanya oleh satu orang hakim saja. Perkara permohonan juga hanya menempatkan satu pihak saja dan tidak ada pihak yang merasa dirugikan haknya. Bahkan dalam pemeriksaan perkara permohonan tidak berlaku asas audi alteram partem dan asas memberikan kesempatan yang sama. Salah satu yang khas dari pengaturan yang ada di dalam sistem small claim procedure adalah tentang boleh atau tidaknya para pihak menggunakan advokat. Menurut Lee P. Arbetman, Edward T. McMahon, dan Edward L. O'Brien, ada beberapa pengadilan (small claim court) tidak mengizinkan para pihak yang beperkara untuk menggunakan jasa advokat. Meskipun demikian, masih ada beberapa small claim court mengizinkan para pihak yang beperkara untuk menggunakan jasa advokat. ${ }^{14}$

\footnotetext{
10 "MA Upayakan Inisiasi Penyelesaian Gugatan Perdata Sederhana."

${ }^{11}$ Lee Arbetman, Edward McMahon, and Edward L O'Brien, Street Law: A Course in Practical Law (Ohio:

McGraw-Hill, 2010), 268.

${ }^{12}$ Fakhriah, "Mekanisme Small Claim Court," 265.

${ }^{13}$ Fakhriah, "Mekanisme Small Claim Court," 268.

${ }^{14}$ Arbetman, McMahon, and O’Brien, Street Law, 268.
} 


\section{Kriteria Perkara dalam Small Claim Procedure}

Perkara-perkara yang masuk ke dalam jenis perkara permohonan ditandai dengan membubuhkan kode "Pdt.P" di dalam nomor registernya. Ada beberapa perkara yang masuk ke dalam jenis perkara permohonan di Pengadilan Agama. Berikut adalah perkara-perkara yang masuk ke dalam kategori perkara perdata permohonan yang berhasil peneliti inventarisir: 1) Permohonan Izin Kawin; 2) Permohonan Wali Adhol; 3) Permohonan Dispensasi Kawin; 4) Permohonan Pencegahan Perkawinan; 5) Permohonan Penetapan Asal-Usul Anak; 6) Permohonan Istbat Nikah; 7) Permohonan Perubahan Identitas Nikah; 8) Permohonan Pengangkatan Wali; 9) Permohonan Pengangkatan Anak; 10) Permohonan Penetapan Ahli Waris. Adapun kriteria perkara yang dapat diajukan sebagai berikut: Pertama, Memiliki nilai materi atau hak yang sederhana. Pembatasan nilai materi yang diperkarakan dalam suatu perkara merupakan ciri utama perkara sederhana yang dapat diperiksa di lingkungan small claim court di negara-negara yang telah menerapkan sistem small claim procedure dalam lingkungan peradilannya.Perkara permohonan merupakan perkara yang tidak mengandung sengketa. Oleh sebab itu dalam perkara permohonan tidak akan terdapat perebutan hak atas suatu materi atau hak yang lain. Hak lain yang dimaksud contohnya adalah hak asuh terhadap seorang anak. Namun karakteristik perkara permohonan yang tidak mengandung sengketa tersebut bukan berarti bahwa dalam perkara permohonan sama sekali tidak ada kaitannya dengan hak seseorang atas suatu materi atau hak yang lain.

Kedua, tuntutan atau permohonannya sederhana. Pada umumnya petitum atau dalil permohonan yang diajukan oleh pemohon dalam perkara permohonannya tidaklah kompleks atau rumit seperti halnya perkara gugatan. Pemohon dalam perkara permohonan notabene hanya meminta apa yang menjadi substansi dari perkara permohonan tersebut, seperti dalam perkara permohonan istbat nikah, maka pemohon hanya meminta kepada hakim agar pernikahan pemohon disahkan.Namun dalam beberapa kasus, permohonan dalam perkara permohonan juga terbilang tidak sederhana. Ketiga, berpotensi diperiksa dalam sekali sidang. Berbeda dengan proses pemeriksaan perkara gugatan, pemeriksaan perkara permohonan lebih sederhana. Dalam pemeriksaan perkara permohonan tidak mengenal proses penyampaian jawaban, serta replik dan duplik. Pemeriksaan perkara permohonan cukup dengan tahapan penyampaian permohonan oleh pemohon dan dilanjutkan dengan pemeriksaan pihak terkait dan pemeriksaan bukti yang diajukan oleh pemohon. Kemudian proses sidang dilanjutkan dengan penyampaian kesimpulan oleh pemohon, musyawarah majelis, dan diakhiri dengan pembacaan penetapan hakim. Oleh karena demikian itu, maka proses pemeriksaan perkara permohonan sangat memungkinkan untuk dapat dilaksanakan hanya dalam satu kali sidang, dengan catatan bahwa pihak pemohon telah menyiapkan bukti untuk diajukan pada sidang pertama tersebut. Namun hal ini mungkin sulit untuk dilaksanakan pada perkara permohonan yang agak rumit, seperti perkara permohonan penetapan ahli waris dan perkara permohonan pengangkatan anak. Penyeleksian perkara sebagai tahap awal proses pemeriksaan perkara permohonan dengan menggunakan sistem small claim procedure merupakan suatu keniscayaan. Hal itu menjadi suatu keharusan karena mengingat bahwa tujuan dari diadakannya sistem small claim procedure adalah untuk memeriksa perkara sederhana agar dapat diperiksa dengan memaksimalkan asas peradilan yang sederhana, cepat, dan biaya ringan.

Keempat, menggunakan hakim tunggal. Hakim berkewajiban untuk memeriksa dan memutus perkara yang telah menjadi tanggungjawabnya. Pada prinsipnya, hakim yang memeriksa suatu perkara haruslah majelis selama undang-undang tidak menentukan yang lain. Majelis itupun harus berjumlah ganjil dengan jumlah minimal 3 (tiga) orang hakim setiap majelisnya. Hal ini telah diamanatkan oleh undang-undang, khususnya Pasal 11 ayat (1) Undang-Undang Nomor 48 Tahun 2009 tentang Kekuasaan Kehakiman. ${ }^{15}$ Seperti yang telah

${ }^{15}$ Pasal 11 ayat (1) Undang-Undang Nomor 48 Tahun 2009 tentang Kekuasaan Kehakiman

Jurisdictie: Jurnal Hukum dan Syariah Vol. 6 No. 1 Tahun 2015 
dijelaskan di atas bahwa pada prinsipnya suatu pemeriksaan perkara haruslah dilakukan oleh hakim majelis agar tidak terjadi subjektifitas. Tujuannya agar para pihak tidak ada yang merasa dirugikan karena merasa hakim memihak kepada pihak yang lain. Namun ketentuan bahwa hakim harus berupa majelis dapat dikecualikan jika undang-undang menghendaki demikian. Sebagai contoh adalah sidang acara pemeriksaan cepat yang digunakan untuk memeriksa perkara tindak pidana ringan, sidang perkara pidana anak, dan juga praperadilan. Sama halnya dengan dua pengecualian di atas, penulis berpendapat bahwa pengadilan agama menerapkan small claim procedure dengan hanya memerintahkan satu hakim untuk memeriksa perkara. Pandangan ini dikuatkan dengan Surat Edaran Mahkamah Agung (SEMA) Nomor 3 Tahun 2014 tentang Tata Cara Pelayanan dan Pemeriksaan Perkara Voluntair Itsbat Nikah dalam Pelayanan Terpadu menyatakan bahwa dalam memeriksa perkara permohonan (voluntair) itsbat nikah, khususnya dalam sidang keliling dapat menggunakan hakim tunggal. ${ }^{16}$ Meskipun peraturan tersebut ditentukan khusus untuk pelaksanaan sidang keliling, namun sidang keliling masih termasuk ke dalam cakupan persidangan oleh pengadilan.

Kelima, hakim pemeriksa harus mengetahui hukum. Pasal 10 ayat (1) Undang-Undang Nomor 48 Tahun 2009 tentang Kekuasaan Kehakiman yang berbunyi "pengadilan dilarang menolak untuk memeriksa, mengadili, dan memutus suatu perkara yang diajukan dengan dalih bahwa hukum tidak ada atau kurang jelas, melainkan wajib untuk memeriksa dan mengadilinya" secara tidak langsung telah mengamanatkan kepada hakim agar hakim selalu siap sedia ketika telah ditunjuk untuk memeriksa suatu perkara. Berdasarkan ketentuan tersebut di atas maka dapat dikatakan bahwa hakim merupakan orang yang dianggap tahu akan hukum suatu perkara yang diajukan oleh pencari keadilan yang dalam konteks penelitian ini adalah pihak pemohon, atau lebih dikenal dengan asas ius curia novit. ${ }^{17}$

Adapun syarat hakim dalam small claim procedure yaitu hakim senior (berpengalaman). Berdasarkan Pasal 13 Undang-Undang Nomor 50 Tahun 2009 tentang Perubahan Kedua atas Undang-Undang Nomor 7 Tahun 1989 tentang Peradilan Agama maka usia minimal seorang hakim di pengadilan agama adalah 25 tahun, dan untuk menjadi wakil ketua atau ketua pengadilan agama, maka seorang hakim harus telah menjadi hakim selama minimal 7 (tujuh) tahun. Menurut penulis bahwa wakil ketua dan ketua pengadilan agama dapat dikatakan sebagai salah satu indikator kesenioran atau acuan seorang hakim dikatakan telah memiliki banyak pengalaman. Seorang hakim yang ditugaskan untuk memeriksa perkara dengan menggunakan sistem small claim procedure harus telah berpengalaman menjadi hakim minimal selama 7 (tujuh) tahun. Selain itu, hakim pemeriksa perkara pernah mengikuti pelatihan. Sebagai suatu sistem yang baru, maka perlu diselengarakan suatu pelatihan untuk hakim agar hakim dalam memeriksa perkara menggunakan sistem small claim procedure sesuai dengan tujuan dan teknisnya. Materi dari pelatihan ini dapat meliputi tentang penguatan tujuan dari adanya small claim procedure, teknis pemeriksaan perkara, penekanan bahwa pemeriksaan perkara dalam small claim procedure dilaksanakan dengan cara sederhana, serta materi lain. Lembaga yang paling berkompeten untuk mengadakan pelatihan ini tidak lain adalah induk dari peradilan agama yaitu Mahkamah Agung. Hakim pemeriksa perkara harus memiliki track record yang bagus. Hakim yang akan diamanatkan untuk memeriksa perkara dengan cara seorang diri harus telah memiliki pengalaman terlsebih dahulu, persis seperti yang dikatakan pada syarat hakim yang pertama, namun pengalaman saja tidak cukup. Selain memiliki pengalaman, hakim juga harus memiliki track record yang bagus selama hakim tersebut menjalankan tugasnya sebagai hakim. Meskipun hakim telah memiliki pengalaman yang cukup lama, namun dalam setiap pemeriksaannya dilakikan dengan cara yang tidak sesuai dengan asas sederhana, cepat, dan

\footnotetext{
${ }^{16}$ Surat Edaran Mahkamah Agung Nomor 3 Tahun 2014 tentang Tata Cara Pelayanan dan Pemeriksaan Perkara Voluntair Itsbat Nikah Dalam Pelayanan Terpadu

${ }^{17}$ Bambang Sutiyoso, Metode Penemuan Hukum: Upaya Mewujudkan Hukum Yang Pasti Dan Berkeadilan (Yogyakarta: UII Press, 2006), 34.
}

Jurisdictie: Jurnal Hukum dan Syariah Vol. 6 No. 1 Tahun 2015 
biaya ringan, maka tujuan dari adanya sistem small claim procederu tidak dapat tercapai. Penentuan bagus tidaknya seorang hakim dalam melaksanakan tugasnya dapat ditentukan oleh ketua pengadilan agama. Meskipun seorang hakim telah memenuhi syarat berpengalaman, serta telah mengikuti pelatihan menjadi hakim tunggal dalam pemeriksaan perkara dengan menggunakan sistem small claim procedure yang diadakan oleh Mahkamah Agung, namun track record seorang hakim juga menentukan apakah hakim tersebut layak untuk menjadi hakim tunggal dalam pemeriksaan suatu perkara. Maka peran ketua pengadilan agama dalam penentuan ini sangat besar.

\section{Prosedur Pemeriksaan Perkara dalam Small Claim Procedure}

Prosedur pemeriksaan perkara permohonan menggunakan small claim procedure tidak jauh berbeda dengan pemeriksaan perkara dengan acara biasa. Perbedaannya, small claim procedure menekankan proses yang lebih sederhana. Meskipun demikian, dalam proses pemeriksaan perkara permohonan hakim tetap wajib memberikan keputusan yang adil dan sesuai dengan hukum yang berlaku. Dalam perkara permohonan hanya ada 1 (satu) pihak yaitu pemohon, sehingga ada beberapa asas peradilan yang akan diabaikan dalam pemeriksaan perkara permohonan, antara lain adalah asas audi alteram partem (hakim mendengarkan dua belah pihak) dan asas memberi kesempatan yang sama kepada dua belah pihak. ${ }^{18}$ Small claim procedure diawali dengan seleksi perkara. Hanya perkara-perkara yang ringan dan sederhana saja yang dapat diselesaikan melalui prosedur ini. Petugas meja satu melakukan seleksi perkara yang akan diperiksa menggunakan sistem small claim procedure dengan mengacu pada peraturan yang telah ada. Tahap selanjutnya adalah menunjuk hakim yang akan memeriksa perkara. Pemeriksaan perkara dalam small claim procedure dilakukan oleh satu hakim. Sehingga perlu dilakukan pemetaan keahlian hakim untuk melaksanakan sidang menggunakan prosedur ini. Pemeriksaan perkara dapat dilakukan hanya dengan satu kali sidang. Namun agar hal itu bisa dilaksanakan, maka pemohon harus menyiapkan bukti untuk diajukan pada sidang yang pertama. Berikut teknis pemeriksaan perkara-perkara permohonan yang ada di pengadilan agama dan sekaligus analisis peneliti jika dikaitkan dengan penerapan sistem small claim procedure: Pertama, Permohonan Izin Kawin: Dasar yuridis permohonan ini terdapat di dalam Pasal 6 ayat (5) Undang-Undang Nomor 1 Tahun 1974 tentang Perkawinan. Pada prinsipnya, seseorang yang bermaksud untuk melaksanakan pernikahan sedang ia belum berusia 21 (dua puluh satu) tahun, maka harus ada persetujuan dari orang tua atau walinya. Namun adakalanya orang tua atau walinya tidak berkehendak untuk memberikan izin tersebut. Dalam keadaan demikian, seseorang yang akanmelangsungkan pernikahan tersebut dapat meminta izin kepada pengadilan agama dengan cara mengajukan permohonan izin kawin. Sebagai pertimbangan, maka orang tua atau wali yang tidak memberikan izin pernikahan tersebut akan dimintai keterangan oleh majelis hakim yang sifatnya sebagai bentuk konfirmasi dan alasan atas penolakan pemberian izin tersebut. Permohonan ini juga dapat mendasar pada Pasal 23 ayat (2) Kompilasi Hukum Islam yang substansinya tentang pembolehan penggunaan wali hakim untuk pernikahan berdasarkan penetapan pengadilan, khususnya pengadilan agama. Dalam pemeriksaan permohonan ini, selain mendengar keterangan dari pemohon, hakim juga akan memanggil wali dari pemohon yang tidak berkenan memberikan izin kepada pemohon untuk melangsungkan pernikahan. Wali yang dipanggil ke dalam sidang tersebut akan dimintai keterangan oleh hakim mengenai alasan wali tersebut tidak memberikan izinnya kepada anaknya tersebut. Keterangan wali tersebut akan menjadi pertimbangan majelis hakim dalam membuat penetapannya. Jika alasan dari penolakan tersebut bukan karena pelanggaran syaratsyarat nikah, maka hakim dapat mengabulkan permohonan dari pemohon. Namun jika alasan tersebut karena pernikahan tersebut tidak memenuhi syarat pernikahan sebagaimana yang ada

${ }^{18}$ M. Yahya Harahap, Hukum Acara Perdata: Tentang Gugatan, Persidangan, Penyitaan, Pembuktian, dan Putusan Pengadilan (Jakarta: Sinar Grafika, 2005), 39. 
di dalam BAB II Undang-Undang Nomo1 Tahun 1974 tentang Perkawinan dan BAB IV Kompilasi Hukum Islam, maka hakim pasti akan menolak permohonan tersebut. Alat bukti yang umum digunakan dalam perkara ini adalah alat bukti saksi.Keterangan dari orang tua atau wali merupakan juga proses pembuktian atas benar atau tidaknya keengganan dari orang tua atau wali untuk memberikan izin kepada pemohon. Lalu alasan-alasan dari orang tua atau wali itulah yang nantinya akan digunakan sebagai pertimbangan hakim dalam menolak ataupun mengabulkan permohonan pemohon. Jika diperhatikan, pemeriksaan perkara ini sangat sederhana.Pemeriksaan perkara ini sangat memungkin untuk dilakukan hanya dalam sekali sidang saja dan dengan pembuktian yang sangat sederhana.

Kedua, Permohonan Wali Adhol: Permohonan wali adhal diajukan oleh calon mempelai perempuan kepada pengadilan agama ketika wali nikahnya tidak berkenan untuk menikahkannya. Oleh sebab itu, hakim dalam pemeriksaan perkara permohonan wali adhol juga akan memanggil wali nikah pemohon untuk dimintai keterangan tentang alasan mengapa wali nikah tidak berkenan untuk menikahkan pemohon. Proses pemeriksaan perkara permohonan wali adhol ini mirip dengan pemeriksaan perkara permohonan izin kawin, bahkan dalam praktiknya perkara permohonan wali adhol sering dikomulasikan dengan permohonan izin kawin karena keengganan wali nikah untuk menjadi wali dalam pernikahan, notabene dibarengi dengan sikap orang tua atau wali untuk menolak memberikan izin kepada putrinya untuk melangsungkan pernikahan. Dengan demikian, perkara permohonan wali adhol sifat kesederhanaannya sama dengan perkara permohonan izin kawin dan sangat memungkinkan untuk dilakukan pemeriksaan dalam satu kali sidang. Ketiga, Permohonan Dispensasi Kawin: Mempelai yang belum memenuhi syarat usia untuk melangsungkan perkawinan dapat diajukan permohonan dispensasi kawin oleh orang tua atau walinya berdasarkan Pasal 7 Undang-Undang Nomor 1 Tahun 1974 tentang Perkawinan. Permohonan ini diajukan oleh orang tua atau wali dari mempelai yang usianya belum mencapai syarat minimal usia perkawinan. Dalam pemeriksaannya, hakim akan memeriksa dan meminta keterangan kepada kedua calon mempelai atas kesiapan masing-masing sehingga hakim dapat mengabulkan atau menolak permohonan tersebut berdasarkan pada keterangan dari pemohon, para saksi yang diajukan, dan kedua calon mempelai. Pemeriksaan perkara permohonan dispensasi kawin sangatlah sederhana dan juga dengan pembuktian yang sederhana karena pemohon cukup memberikan bukti dan keterangan yang menguatkan bahwa calon mempelai siap untuk melangsungkan perkawinan dengan segala konsekuensinya.

Keempat, Permohonan Pencegahan Perkawinan: Permohonan pencegahan perkawinan berdasar pada Pasal 13 junto Pasal 17 ayat (1) Undang-Undang Nomor 1 Tahun 1974 tentang Perkawinan. Permohonan pencegahan perkawinan diajukan ketika ada yang mengetahui bahwa ada syarat-syarat perkawinan yang tidak dipenuhi oleh sepasang calon pengantin yang akan melangsungkan perkawinan. Pemohon dapat mengajukan bukti-bukti yang dapat memperkuat dalil-dalilnya, seperti akta otentik maupun bukti saksi yang mengetahui bahwa terdapat syarat yang tidak terpenuhi oleh calon mempelai yang akan melangsungkan pernikahan. Selama pemohon dapat mengajukan bukti yang dapat menguatkan dalil-dalilnya, maka hakim juga akan dapat segera memberikan putusan. Oleh sebab itu, perkara ini dapat dikategorikan perkara yang prosesnya sederhana dan juga memungkinkan untuk diperiksa dalam satu kali sidang. Kelima, Permohonan Penetapan Asal Usul Anak: Pasal 103 ayat (2) Kompilasi Hukum Islam memberikan kesempatan kepada anak yang tidak memiliki akta kelahiran atau yang semacamnya untuk memilikinya dengan cara mengajukan permohonan penetapan asal usul anak ke pengadilan agama terlebih dahulu. Selain disebabkan hal di atas, permohonan penetapan asal-usul anak juga dapat diajukan ketika tanggal lahir anak yang terdapat di dalam akta kelahiran lebih awal dibandingkan dengan tanggal register pernikahan orang tuanya yang tercantum di dalam buku nikah. Hal itu dapat terjadi ketika pernikahan antara suami istri baru dicatatkan di kantor urusan agama setelah mereka memiliki anak karena antara suami dan istri 
tersebut terlebih dahulu melakukan pernikahan di bawah tangan atau juga disebut dengan pernikahan sirri. Maka untuk mendapatkan kepastian tentang asal-usul anak secara sah, diperlukan penetapan hakim yang menetapkan bahwa anak tersebut merupakan anak sah dari orang tuanya. Dalam pemeriksaan perkara permohonan asal-usul anak ini, hakim akan memeriksa secara teliti keterangan pemohon, keterangan saksi-saksi, serta bukti-bukti lain yang diajukan oleh pemohon. Proses pembuktian untuk perkara permohonan asal-usul anak ini juga dapat dilakukan dengan cara sederhana. Sebagai gambaran, pemohon dapat mengajukan bukti berupa saksi-saksi yang mengetahui proses pernikahan antara pemohon (suami-stri) yang dilakukan sebelum akhirnya pernikahan tersebut didaftarkan ke kantor urusan agama setelah anaknya lahir. Maka dapat ditarik kesimpulan bahwa pemohon cukup membuktikan kepada hakim akan sahnya pernikahan yang dilakukan oleh pemohon sebelum memiliki anak tersebut. Pembuktian ini pun relatif sederhana sehingga memungkinkan bagi hakim untuk melakukan pemeriksaan dalam jumlah sidang yang juga relatif sedikit, bahkan bisa diputus hanya dalam 1 (satu) kali sidang.

Ketujuh, Permohonan Pengangkatan Wali: Pada prinsipnya orang tua baik ayah maupun ibu secara normative menjadi wali dari anak kandungnya. Namun pada praktiknya, beberapa tindakan hukum yang akan dilakukan oleh ayah atau ibu terhadap harta yang menjadi hak milik anaknya memerlukan penetapan pengadilan atas perwalian dari ayah atau ibu anak tersebut. ${ }^{19}$ Oleh sebab itu orang tua yang menghadapi urusan demikian dapat mengajukan permohonan pengangkatan wali kepada pengadilan agama. Proses pemeriksaan perkara permohonan pengangkatan wali sangat sederhana. Pemohon cukup menunjukkan bukti bahwa anak yang dimaksud benar-benar anaknya. Bukti yang digunakan dapat berupa bukti tertulis akta otentik seperti Kartu Keluarga serta akta kelahiran anak maupun alat bukti yang lain. Oleh karena itu pemeriksaan perkara permohonan pengangkatan wali seperti kasus di atas dapat dilakukan dengan sederhana dan waktu pemeriksaan yang tidak lama. Kedelapan, Permohonan Perubahan Identitas Akta Nikah: Akta pernikahan atau biasa juga disebut dengan buku nikah menjadi hal utama yang harus diajukan ketika seseorang mengurus urusan administrasi, seperti pembuatan akta kelahiran anak.Kesalahan penulisan identitas di dalam buku nikah dapat menimbulkan berbagai masalah di kemudian hari.Oleh sebab itu, identitas di dalam buku nikah harus sinkron dengan dokumen penunjuk identitas yang lain seperti Kartu Tanda Penduduk (KTP), Kartu Keluarga (KK), ijazah, dan lain sebagainya.Namun pada kenyataannya sering terjadi kesalahan penulisan identitas di dalam buku nikah, dan kesalahan tersebut harus dibetulkan. Solusi dari masalah tersebut tidak lain adalah dengna cara mengajukan permohonan ke pengadilan agama, yaitu permohonan perubahan identitas kawin. Proses pemeriksaan perkara permohonan perubahan identitas sangat sederhana. Pemohon cukup menunjukkan bukti yang mendukung dalil-dalil permohonannnya, lebih tepatnya bukti yang menunjukkan identitas yang benar seperti yang dikehendaki oleh pemohon. Alat bukti yang dapat dipilih oleh pemohon adalah alat bukti tertulis, khususnya akta otentik seperti Kartu Tanda Penduduk, Ijazah, dan lain sebagainya.Maka perkara ini dapat dikategorikan perkara yang sederhana dan sangat memungkinkanuntuk diperiksa dan diputus dalam 1 (satu) kali sidang saja.

Kesembilan, Permohonan Istbat Nikah: Pasangan suami istri yang menikah sebelum diterbitkannya Undang-Undang Nomor 1 Tahun 1974 tentang Perkawinan dapat mengajukan permohonan istbat nikah untuk bisa meregistrasikan pernikahannya serta mendapatkan akta nikah. Selain itu, pernikahan yang dilakukan tidak di hadapan pegawai pencatat pernikahan atau juga disebut dengan pernikahan di bawah tangan juga dapat mengajukan perkara permohonan istbat nikah untuk kepentingan perceraian. Namun permohonan istbat nikah yang masuk dalam kategori perkara permohonan dengan kode register "Pdt.P" adalah perkara

${ }^{19}$ Nurul Maulidah, Wawancara, (Kepanjen, 30 Januari 2015).

Jurisdictie: Jurnal Hukum dan Syariah Vol. 6 No. 1 Tahun 2015 
permohonan istbat nikah yang diajukan oleh suami dan istri dalam satu perkara. Sama halnya dengan pemeriksaan perkara permohonan asal-usul anak, perkara pemeriksaan perkara permohonan istbat nikah juga dititikberatkan pada pembuktian sahnya pernikahan yang dilakukan oleh sepasang suami-istri.Maka untuk dapat menguatkan dalil-dalail permohonannya, pemohon harus dapat membuktikan sahnya perkawinan yang sudah dilakukannya. Alat bukti yang dapat diajukanpun sama seperti alat bukti yang juga biasa digunakan dalam perkara permohonan asal-usul anak, begitu juga dengan sifat kesederhanan pemeriksannya yang juga sama-sama sederhana.

Kesepuluh, Permohonan Pengangkatan Anak: Salah satu kewenangan pengadilan agama adalah memeriksa perkara permohonan pengangkatan anak beragama Islam dan berkewarganegaraan Indonesia oleh pemohon yang beragama Islam dan berkewarganegaraan Indonesia. Perkara pengangkata anak akan menjadi perkara volunteer atau perkara permohonan ketika anak yang akan diadopsi tidak sedang berada di bawah kekuasaan orang tua atau wali yang lain. Jika anak yang akan diadopsi sedang berada di bawah kekuasaan orang lain, maka pengajuan perkara pengangkatan anak menjadi perkara gugatan atau kontentius. Perkara ini tergolong cukup rumit karena pemohon harus memenuhi syarat-syarat yang telah ditetapkan di dalam Undang-Undang Nomor 23 Tahun 2002 tentang Perlindungan Anak, Undang-Undang Nomor 12 Tahun 2006 tentang Kewarganegaraan Republik Indonesia, Peraturan Pemerintah Nomor 54 Tahun 2007 tentang Pelaksanaan Pengangkatan Anak, SEMA RI Nomor 2 Tahun 1979, SEMA RI Nomor 6 Tahun 1983, dan SEMA RI Nomor 3 Tahun 2005.

Dalam Peraturan Pemerintah Nomor 54 Tahun 2007 tentang Pelaksanaan Pengangkatan Anak, ada beberapa syarat yang harus dipenuhi baik dari segi anak maupun dari pihak pemohon itu sendiri. Berikut persyaratan yang harus dipenuhi oleh pemohon: a) sehat jasmani dan rohani; b) berumur paling rendah 30 (tiga puluh) tahun dan paling tinggi 55 (lima puluh lima) tahun; c) beragama sama dengan agama calon anak angkat; d) berkelakuan baik dan tidak pernah dihukum karena melakukan tindak kejahatan; d) berstatus menikah paling singkat 5 (lima) tahun; e) tidak merupakan pasangan sejenis; f) tidak atau belum mempunyai anak atau hanya memiliki satu orang anak; g) dalam keadaan mampu ekonomi dan sosial; h) memperoleh persetujuan anak dan izin tertulis orang tua atau wali anak; i) membuat pernyataan tertulis bahwa pengangkatan anak adalah demi kepentingan terbaik bagi anak, kesejahteraan dan perlindungan anak; $j$ ) adanya laporan sosial dari pekerja sosial setempat; $k$ ) telah mengasuh calon anak angkat paling singkat 6 (enam) bulan, sejak izin pengasuhan diberikan; dan l) memperoleh izin Menteri dan/atau kepala instansi sosial. ${ }^{20}$ Syarat-syarat yang tergolong banyak dan kesemuanya wajib dipenuhi oleh pemohon menimbulkan konsekuensi tersendiri bagi hakim yang memeriksa permohonannya.Hakim secara tidak langsung juga harus memeriksa persyaratan-persyaratan tersebut. Selain memeriksa persyaratan yang bersifat normatif tersebut, demi kepentingan anak, hakim juga harus memperhatikan sisi sosial dan psikologis beberapa orang, baik dari pihak pemohon, anak yang diangkat, juga pihak keluarga atau wali dari anak tersebut. Banyaknya persyarat tersebut juga berdampak pada waktu yang dibutuhkan untuk memeriksa perkara tersebut.Oleh sebab demikian, maka perkara permohonan pengangkatan ini dapat dianggap sebagai perkara yang rumit dalam pemeriksaannya.

Kesebelas, Permohonan Penetapan Ahli Waris: Pembagian harta waris dapat juga dibagi berdasarkan penetapan hakim.Pemohon yang ingin membagi harta waris berdasarkan penetapan hakim dapat mengajukan permohonan penetapan ahli waris.Namun permohonan ini hanya sebatas penetapan siapa saja yang berhak menjadi ahli waris. Karakteristik perkara permohonan penetapan ahli waris yang sedemikian rupa, menuntut agar hakim aktif dalam mengumpulkan informasi tentang siapa saja yang berhak untuk menjadi ahli waris.Hakim harus melakukan pemeriksaan dengan ketelitian yang lebih teliti agar tidak ada ahli waris yang

\footnotetext{
${ }^{20}$ Pasal 14 Peraturan Pemerintah Nomor 54 Tahun 2007 tentang Pelaksanaan Pengangakatan Anak.
} 
tertinggal dalam penetapan.Kepastian dari jumlah ahli waris dapat ditemukan oleh hakim melalui pemeriksaan dalam sidang. Hakim juga sebisa mungkin harus membuat pemohon agar dapat menyampaikan siapa saja yang sekiranya bisa menjadi ahli waris menurut hakim melalui pemeriksaan tanya jawab di dalam persidangan maupun melalui bukti-bukti yang disampaikan oleh pemohon. Hakim dapat meminta beberapa bukti, baik bukti tertulis maupun saksi untuk mengungkap siapa saja yang berhak menjadi ahli waris.Para ahli waris tersebut harus menjadi pihak pemohon. Jika diketahui ada ahli waris yang belum menjadi pihak dalam perkara tersebut, maka hakim akan meminta kepada pemohon agar orang tersebut dimasukkan menjadi pihak juga. Maka jika pemohon awal tidak memasukkan nama orang tersebut, maka hakim dapat menolak untuk memeriksa perkara tersebut karena pemohon tidak sesuai dalam mengajukan permohonannya. Karakteristik pemeriksaan yang demikian menjadikan perkara ini tergolong bukan perkara yang sederhana. Selain itu, pemeriksaan perkara permohonan penetpan ahli waris juga akan memakan banyak waktu karena hakim harus sangat teliti dalam menemukan siapa saja yang berhak menjadi ahli waris.

\section{Perumusan Peraturan Small Claim Procedure}

Sistem small claim procedure merupakan suatu sistem yang baru di lingkungan peradilan Indonesia. Sehingga belum terdapat regulasi tentang small claim procedure. Oleh karena belum ada regulasi yang mengatur tentang sistem small claim procedure, maka perlu dibuatkan suatu regulasi yang dituangkan di dalam peraturan perundang-undangan maupun bentuk peraturan lain yang dapat diberlakukan di sistem peradilan Indonesia, khususnya di dalam lingkungan pengadilan agama. Selain alasan tersebut, perlunya dibentuknya suatu aturan tentang sistem small claim procedure yang dituangkan dalam bentuk regulasi yang dapat diberlakukan di lingkungan pengadilan agama juga bertujuan agar tidak terjadi multi tafsir sehingga terdapat kepastian hukum.

Ada beberapa bentuk peraturan yang dapat diberlakukan di lingkungan pengadilan agama, antara lain adalah perundang-undangan dan produk hukum dari Mahkamah Agung, seperti Peraturan Mahkamah Agung, Keputusan Ketua Mahkamah Agung khususnya yang bersifat mengatur, serta Surat Edaran Mahkamah Agung. Jika sistem small claim procedure dapat dituangkan ke dalam bentuk undang-undang, maka peraturan ini memiliki tingkatan yang benar-benar tinggi, namun untuk membentuk suatu undang-undang memerlukan waktu yang sangat lama karena proses pembentukan suatu undang-undang tidaklah sederhana. Opsi berikutnya adalah merumuskan regulasi sistem small claim procedure ke dalam bentuk Peraturan Mahkamah Agung atau biasa disingkat dengan PERMA. Proses pembentukan regulasi ke dalam bentuk PERMA lebih sederhana karena pembahasannya berada di dalam internal Mahkamah Agung, namun hierarki menentukan bahwa posisi PERMA masih berada di bawah undang-undang, sehingga PERMA tidak boleh bertentangan dengan undang-undang, sedangkan di dalam Undang-Undang Nomor 48 Tahun 2009 tentang Kekuasaan Kehakiman telah diatur bahwa hakim dalam memeriksa suatu perkara harus terdiri dari majelis.

Pasal 11 ayat (1) Undang-Undang Nomor 48 Tahun 2009 tentang Kekuasaan Kehakiman memiliki redaksi "pengadilan memeriksa, mengadili, dan memutus perkara dengan susunan majelis sekurang-kurangnya 3 (tiga) orang hakim, kecuali undang-undang menentukan lain". Secara eksplisit pasal tersebut menentukan bahwa yang dapat mengecualikan ketentuan bahwa hakim harus majelis hanyalah undang-undang. Namun peneliti berpendapat bahwa frasa "undang-undang" tidak memiliki arti sebagaimana yang dimaksud di dalam Pasal 1 ayat (3) Undang-Undang Nomor 12 Tahun 2011 tentang Pembentukan Peraturan Perundang-undangan, yaitu "Peraturan Perundang-undangan yang dibentuk oleh Dewan Perwakilan Rakyat dengan persetujuan bersama Presiden". Frasa "undang-undang" yang terdapat di dalam Pasal 11 ayat (1) Undang-Undang Nomor 48 Tahun 2009 tentang Kekuasaan Kehakiman tersebut ditafsiri sebagai "peraturan perundang-undangan" sebagaimana yang tercantum di dalam Pasal 1 ayat 
(1) Undang-Undang Nomor 12 Tahun 2011 tentang Pembentukan Peraturan Perundangundangan yang berbunyi "peraturan perundang-undangan adalah peraturan tertulis yang memuat norma hukum yang mengikat secara umum dan dibentuk atau ditetapkan oleh lembaga negara atau pejabat yang berwenang melalui prosedur yang ditetapkan dalam Peraturan Perundang-undangan".

Berdasarkan pengertian "peraturan perundang-undangan" tersebut, maka Mahkamah Agung selaku lembaga negara yang memegang kekuasaan kehakiman juga dapat membuat suatu produk hukum yang dapat diberlakukan di pengadilan-pengadilan yang berada di bahwa Mahkamah Agung, salah satunya adalah pengadilan agama. Hal ini juga diperkuat di dalam Pasal 8 Undang-Undang Nomor 12 Tahun 2011 tentang Pembentukan Peraturan Perundangundangan yang pada substansinya menjelaskan bahwa peraturan yang ditetapkan oleh beberapa lembaga Negara Indonesia yang salah satunya adalah Mahkamah Agung, merupakan peraturan perundang-undangan. Maka dapat disimpulkan bahwa produk hukum dari Mahkamah Agung dapat mengecualikan yang mengatakan bahwa pengadilan harus memeriksa, mengadili, dan memutus perkara harus menggunakan hakim majelis. Pendapat peneliti tersebut juga diperkuat dengan dikeluarkannya Surat Edaran Mahkamah Agung Nomor 3 Tahun 2014 tentang Tata Cara Pelayanan dan Pemeriksaan Perkara Voluntair Itsbat Nikah Dalam Pelayanan Terpadu yang salah satu poinnya adalah memberikan peluang kepada pengadilan agama untuk melakukan pemeriksaan perkara dengan menggunakan hakim tunggal.

\section{Kesimpulan}

Berdasarkan pembahasan di atas, small claim procedure dapat diterapkan di pengadilan agama, untuk memeriksa dan memutus perkara permohonan (volunter) dengan pertimbangan substansi perkara yang diajukan bersifat sederhana. Meskipun demikian, hakim yang memeriksa perkara iniharus memeliki pengalaman dan kecakapan dalam menangani perkara permohonan. Agar sistem ini dapat diberlakukan di pengadilan, konsep ini perlu dirumuskan dalam bentuk Peraturan Mahkamah Agung. Suatu permohonan termasuk perkara yang sederhana jika memiliki nilai materi atau hak yang sederhana, permohonannya sederhana, dan sangat memungkinkan untuk diperiksa dalam satu kali sidang. Berdasarkan kriteria tersebut, ada delapan jenis perkara yang dapat diperiksa menggunakan sistem small claim procedure yaitu: permohonan izin kawin, permohonan wali adhol, permohonan dispensasi kawin, permohonan pencegahan perkawinan, permohonan penetapan asal-usul anak, permohonan istbat nikah, permohonan perubahan identitas nikah, dan permohonan pengangkatan wali.

\section{Daftar Pustaka}

Amiruddin, and Zainal Asikin. Pengantar Metode Penelitian Hukum. Jakarta: RajaGrafindo Persada, 2012.

Arbetman, Lee, Edward McMahon, and Edward L O'Brien. Street Law: A Course in Practical Law. Ohio: McGraw-Hill, 2010.

Fakhriah, Efa Laela. "Mekanisme Small Claim Court Dalam Mewujudkan Tercapainya Peradilan Sederhana, Cepat, Dan Biaya Ringan." Mimbar Hukum 25, no. 2 (April 2013).

Harahap, M. Yahya. Hukum Acara Perdata: Tentang Gugatan, Persidangan, Penyitaan, Pembuktian, dan Putusan Pengadilan. Jakarta: Sinar Grafika, 2005.

"MA Upayakan Inisiasi Penyelesaian Gugatan Perdata Sederhana," October 28, 2014. http://www.pembaruanperadilan.net/v2/2014/04/ma-upayakan-inisiasi-penyelesaiangugatan-perdata-sederhana/.

"Mahkamah Agung Republik Indonesia." Accessed December 8, 2016. https://www.mahkamahagung.go.id/id/berita/361/pengadilan-untuk-semua. 
Marzuki, Peter Mahmud. Penelitian Hukum. Jakarta: Kencana, 2010.

Peraturan Pemerintah Nomor 54 Tahun 2007 tentang Pelaksanaan Pengangakatan Anak

Sutiyoso, Bambang. Metode Penemuan Hukum: Upaya Mewujudkan Hukum Yang Pasti Dan Berkeadilan. Yogyakarta: UII Press, 2006.

Surat Edaran Mahkamah Agung Nomor 3 Tahun 2014 tentang Tata Cara Pelayanan dan Pemeriksaan Perkara Voluntair Itsbat Nikah Dalam Pelayanan Terpadu

Undang-Undang Nomor 48 Tahun 2009 tentang Kekuasaan Kehakiman

Undang-Undang Dasar Negara Republik Indonesia

Undang-Undang Nomor 50 tahun 2009 tentang Peradilan Agama 